\title{
Foreign Aid, Aid Effectiveness and the New Aid Paradigm: A Review
}

\author{
H. Gunatilake, R.V. Fabella, and A. Lagman-Martin *1
}

\begin{abstract}
This paper reviews the co-evolution of thoughts on development and foreign aid, and empirical findings on aid effectiveness. The review recognizes the emergence of a new aid paradigm. The new aid paradigm embraces a set of principles such as holistic long-term development strategy; enabling policy and institutional environment; good governance; country ownership; simplified and harmonized aid procedures; increased reliance on and alignment with government systems and procedures; mutual accountability and partnership; ex-post conditionality or selectivity; predictability of aid flows; and results-based management. The paper shows that these principles are largely knowledge-based and able to make aid more effective, in theory. Achieving results in practice, however, requires challenging changes within donor agencies as well as recipient country governments. The paper also outlines the major challenges ahead in implementing the new aid paradigm.
\end{abstract}

\section{Introduction}

Foreign aid is one of the important determinants of development outcomes in developing countries. Over the last 60 years, the development priorities of donor agencies and recipient countries evolved - either reflecting new development thinking, or responding to changes in the development landscape, or in response to empirical findings on aid effectiveness - and so has the aid delivery architecture ${ }^{2}$. This paper surveys the economic rationale of foreign aid, the co-evolution of thoughts on development and foreign aid, and responses of development agencies to changing development challenges/priorities over time.

\footnotetext{
* Authors are, respectively, Lead Energy Economist, Asian Development Bank (ADB), Philippines, Professor, School of Economics, University of the Philippines and Economics Officer, ADB, Philippines.

${ }^{1}$ The opinions reflects in this paper do not represent views or the policies of the Asian Development Bank

2 Aid architecture refers to a set of rules and institutions governing aid flows. While institutions matter in aid effectiveness, this paper focuses mainly on a set of rules or development thoughts currently believed to be effective in delivering development outcomes.
} 
To put the review in proper perspective, we first train a quick glance at the trajectory of foreign aid flows (see Kharas 2007 for a detailed discussion on aid flows). The average annual aid flows ${ }^{3}$ from donors to developing countries have shown a generally increasing trend since the 1960s. Before the 1990s, Asia received the bulk of aid flows, followed closely by Africa; after the 1990s, aid to Africa overtook aid to Asia (Figure 1). The ramp-up of aid to Africa has also been remarkable compared to other regions. Growth performance, on the other hand, exhibited similar trends across regions, with distinct spikes in Europe. Figure 2 depicts a disturbing picture when compared to the trend of aid inflows, particularly for Africa. Despite receiving the largest aid inflows after the 1990s, Africa's growth record was not impressive. It must be noted, however, that a large part of foreign aid to Africa since 1996 involved grants for debt forgiveness, meaning no new aid. In contrast, Asia's growth performance was extraordinary. The growth of gross domestic product (GDP) in Asia was highest since the 1980s and exhibited a large take off from the 1990s, almost catching up with the high growth rates in the early years under review.

Figure 1: ODA to developing countries (annual average)

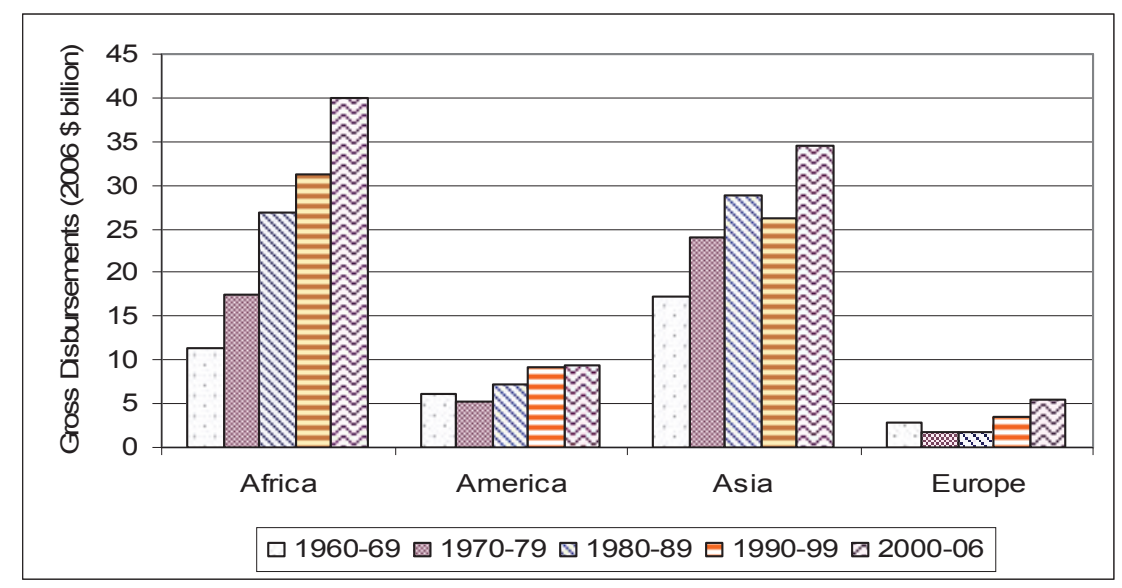

Note: ODA = official development assistance from all donors.

Source: OECD stat.

\footnotetext{
3 Measured by gross disbursement in 2006 constant dollar terms.
} 
41

Figure 2: GDP growth rate in developing countries (annual average)

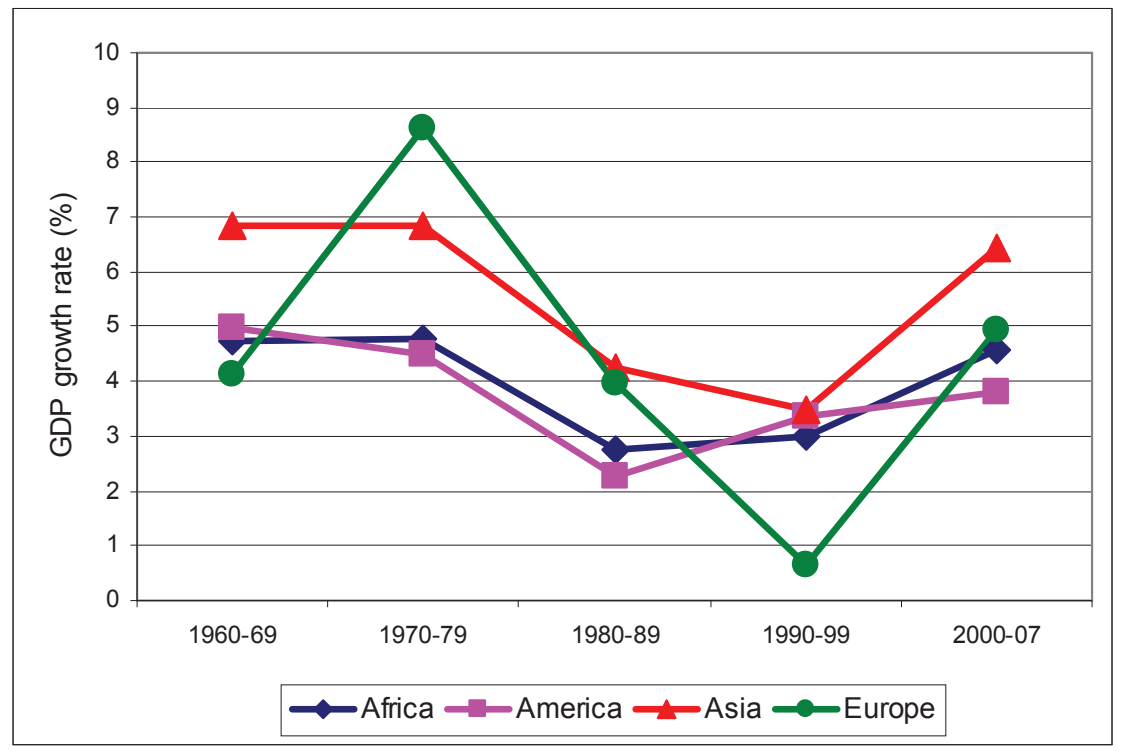

Note: GDP = gross domestic product. Developing countries per OECD classification. Source: World Development Indicators Database.

The Figure 2 reveals that the magnitude of foreign aid alone cannot predict growth outcomes. The premise that foreign aid is an important determinant of development outcome needs to be qualified, particularly with respect to the various characteristics, and the environment surrounding the delivery and effective use of aid. The long standing question is whether and under what conditions foreign aid is effective in delivering development impacts. While there is no simple answer to this question, a more pertinent practical question is how can aid be made more effective? This paper aims to shed some light on these questions focusing on the aid effectiveness literature and evolution of aid thoughts.

Motivation for as well as the focus in aid giving has evolved since the end of the Second World War when aid giving begun in earnest. In the 1950s, it was solely capital deficit that drove aid giving. Concepts of technology gaps in the 1960s, growth with equity in the 1970s, balance of payment (BOP) support and stabilization in the 1980s, and structural adjustments in the late 1980s and early 1990s dominated aid giving. In the late 1990s, problems associated with the Asian financial and other crises led to the emergence of program aid for debt relief. The first decade of the $21^{\text {st }}$ century witnessed a growing recognition of the central importance of institutions, which prompted lending and technical assistance for institutional and governance reform. The growing awareness of government and institutional failures prompted a 
review of the government as the sole conduit of aid and recognition of the possibility that other players, e.g., the private sector and civil society organizations, may play some role in aid operations. Likewise, the early 2000 s witnessed the emphasis on poverty reduction by donors, the centerpiece of which is the United Nations' (UN) millennium development goals (MDGs).

Having gone through so many changes, the aid thoughts have evolved into a new orthodoxy, which this paper describes as "new aid paradigm" The question remains whether the newfangled attributes of today's aid architecture are foisted only to defuse the criticisms leveled against aid agencies or that these are really meant to address the evolving challenges. To what extent does the new aid paradigm reflect findings of aid effectiveness studies and development lessons? These are some of the issues that this review aims to address.

The paper is organized as follows. The next section provides a brief discussion of the economic rationale for foreign aid. Section III reviews the historical evolution of ideas on foreign aid and the development theories that supported them. Section IV provides a succinct summary of the major empirical findings of the aid effectiveness literature and a view of how the findings have influenced the current aid thoughts. Section V discusses how donor and recipient dysfunctions influence aid delivery and impact on aid effectiveness. Section VI summarizes the current aid thoughts as embodied in the new aid paradigm and describes how the donors have responded to evolving aid thoughts. This section also briefly discusses the main challenges in implementing the new aid agenda underpinned by the new aid paradigm. The final section summarizes the major findings of the review.

\section{Rationale for Foreign Aid}

The Development Assistance Committee (DAC) defines official development assistance (ODA) as the sum of grants and loans provided by donor country governments to aid recipient countries, with the objective of promoting economic development and welfare, at concessional financial terms. These include loans which have a grant element of at least $25 \%$ (OECD-DAC's Glossary). The DAC subsumes foreign aid under ODA (Lavergne and Alba, 2003). ODA does not include flows for military purposes and transfers to nongovernment organizations (NGOs). The DAC's definition of ODA may, however, be restrictive as many NGOs now receive aid. Private donors and foundations are also becoming important. A more general and accommodative definition of foreign aid may be the following: any resource flow intended for developmental purposes in recipient countries, with a grant element of at least $25 \%$ of face value. On the other hand, foreign aid may be 
equated with Effective Development Assistance (EDA), which includes grants and grant equivalents of concessional loans, which comes out to be lower in aggregate than ODA.

A pertinent question to begin the discussion on foreign aid is, why foreign aid? A simple way to frame the response is to view the question first from the supply side and then from the demand side of the aid contract. The supply or the donor's side of the aid contract consists of motives and resource availability. Donor motives can be either altruistic or non-altruistic. The altruistic motive can be either humanitarian or developmental. The humanitarian motive underlies humanitarian aid under crisis situations (for example, food aid and emergency relief). The developmental motive is driven by global poverty-aversion or a regard for so called "global public goods" such as peace and security, fair international trade rules, control of communicable diseases, financial stability, biodiversity, and global climate (Kanbur and Sandler, 1999; Azam and Laffont, 2003; Cordella and Dell'Ariccia, 2003).

The non-altruistic motive for aid comes generally under the rubric of either the foreign policy motive or the commercial motive. The foreign policy motive is associated with the "security motive" so important during the Cold War era and becoming so again after 9/11. Commercial motives may be explicit as when market access or the award of an earmarked commercial contract is being sought in return for aid. Sometimes, non-altruistic motives may be manifested in what is known as "defensive lending" (Birdsall et al., 2003; Geginat and Kraay, 2007), i.e., lending to prevent default on previous loans.

Purity of motive is seldom the rule in aid giving. For example, global poverty-aversion may commingle with selfish aversion for the cross-border negative externality of poverty (such as unwanted migration, opium trade dependency), terrorism, or global environmental degradation. Motives are important because they determine the type of aid (e.g., security motive translates into military aid) while aid effectiveness is generally defined with respect to some global public goods (poverty reduction or growth). The rest of the paper deals only with aid provided for developmental motives. When donors' desire to provide global public goods is matched with economic surplus, the supply side of the aid contract becomes complete, that is, funds are made available for aid.

The demand or recipient's side of the aid contract consists of motives of recipient countries to borrow from donors. Developing countries which need financial resources for investments and other developmental purposes either: (i) do not have enough resources locally, or (ii) are unable to access 
44

foreign savings on commercial terms due to market and/or policy/institutional failures, or combinations of the two. When demand equals supply, the aid flow occurs. Because aid is expected to correct existing market and nonmarket failures, it can potentially be welfare improving.

The prevalence of market and nonmarket failures in developing countries and their inability to finance all their developmental needs provide a rationale for foreign aid. To further delve into the "why aid" question we need to look more closely at the international capital markets. Stiglitz and Weiss (1981) have demonstrated that capital markets are, at their cores, subject to severe "asymmetric information" so that price (interest rate) fails as an efficient allocation device. The consequences of this are that:

(i) Good projects in developing countries go un-financed due to (a) capital deficits in those countries, and (b) the reluctance of outsiders to carry the fiduciary risks associated with financing those projects (unless, but sometimes even when, covered by sovereign guarantees).

(ii) Many good projects which (a) have long gestation periods and thus, substantial social benefits accruing too far into the future; and (b) may have the highest social returns, but are nonrevenue generating projects, cannot normally be financed from commercial bank borrowing because the repayment obligation cannot be met out of revenues.

Thus, the rationale for foreign aid partly lies in the fact that capital markets are imperfect. Apart from asymmetric information-based market failures, there is the even bigger problem of political risk, which commercial players are unable to ensure against completely. Furthermore, adverse random shocks such as terms-of-trade or contagion-related risks cannot be completely diversified away. These tend to result in poorer developing countries being bypassed by the global commercial capital markets (USAID, 1984). In addition, foreign direct investments (FDIs) and portfolio flows flock to countries that offer good profit potential with low downside risks-good and stable macro economic environment, good governance, reliable contract enforcement, good basic infrastructure and political stability-most of which are lacking in the poorest developing countries. Under the "development bank paradigm" (coined by Klein and Harford, 2005), foreign aid channeled through development banks can help bridge the yawning gap of development financing between the poorest developing countries and the externally available financing services by overcoming both market failures and institutional failures. On top of this traditional role, three very important development bank roles evolved over time: (i) finance the adjustment and other costs of the effort to ameliorate the institutional and policy obstacles toward creating an enabling environment for investments to be effective; (ii) extend catalytic equity investment to private enterprises to promote private 
45

sector investment; and (iii) mitigate risk to private lenders and private investors by providing some form of guarantee for institutional failures.

\section{Co-Evolution of Aid and Development Thoughts}

\section{Formative Events and Related Theories}

The Marshall Plan that oversaw the post-world war II reconstruction of Western Europe was the model that shaped aid thinking in the subsequent three decades. The motives behind the Marshall Plan were varied (Tarp, 2006). One was altruism directed toward alleviating suffering and destitution in war-ravaged Europe. Another was the pressing need to contain the growing influence of Communist Russia whose sphere had just been expanded and whose sheen, built up during the Great Depression, had only grown. So compelling was the ideological and foreign policy driver of the Marshall Plan that the USA dedicated between $2-3 \%$ of its yearly national income to the enterprise.

The Marshall Plan's biggest draw in subsequent decades was its spectacular success. Financing the massive physical reconstruction of Europe, the Marshall Plan quickly crowded in economic activity and laid the cornerstone of the "30 Glorious Years" of European recovery. It was the perfect response to post-war Europe's massive "financing gap". From originally financing imports and balance of payments support, the Marshall Plan embraced project aid as the dominant delivery modality (Tarp, 2006).

The 1950s and 1960s also saw many former colonies attain political independence from their colonial masters. Apart from exuberant nationalism, these newly independent states were also destitute, in great haste, and faced huge capital gaps. They were also increasingly being reminded of how Soviet Russia had moved rapidly from the backwaters to the leading edge of development. The Cold War made third world countries both the arena and the prize of the clash between the market and centrally planned economy ideologies. If the International Bank for Reconstruction and Development (IBRD, now World Bank) and the International Development Association (IDA) could replicate mini-Marshall Plans in the third world, a phalanx of pro-market allies would have been formed. These events, which shaped subsequent aid attitude in the West, had support from and in turn supported prevailing developmental theories.

The Marshall Plan suggested a paradigm for third world country development. The intellectual underpinning was Rosenstain-Rodan's "Big Push" (1943, 1961), a tribute to the concepts of external economies, 
complementarity, and social returns. As the MIT Center for International Studies (1957) put it:

"There is a minimum level of resources that must be devoted to...a development program if it is to have any chance of success. Launching a country into self-sustaining growth is a little like getting an airplane off the ground. There is a critical ground speed which must be passed before the craft can become airborne..."

Rosenstain-Rodan argued that indivisibilities and market failures abound in third world economies which give rise to increasing returns and external economies but which will not be harnessed by private profit calculus. It is thus the duty of the state to provide the social overhead capital. However, the modicum of financing of requisite investment may be afforded by the economy, especially one coming out of the war. Thus, he proposed in 1943 the "Eastern European Industrial Trust" to finance the capital requirement of eastern and south-eastern Europe when the war ended.

The Big Push idea spawned important corroborations and articulation. Nurkse (1953) advocated "balanced growth" or "a frontal attack - a wave of capital investments in a number of different industries." Nelson (1956) formulated the concept of the low-level equilibrium trap which motivated the "critical minimum effort" and the "critical ground speed" viewpoint. Leibenstein (1957) articulated the "critical minimum effort" idea. Hirschman (1958) introduced the idea of "backward and forward linkages". Rostow (1960) proposed the stages of economic growth centered on the "take-off" stage, which is achieved "when the scale of productive economic activity reaches a critical level and produces changes which lead to massive and progressive structural transformation". It is interesting to note that the subtitle of Rostow's book (A Non-Communist Manifesto) showed that it was meant to pose a challenge to the Marxist prescription for third world economic catchup. Rostow influenced US foreign policy toward aiding least developed countries (LDCs) to attain take-off. The idea was to create a bulwark against the Soviet sphere expansion with a string of progressive third world capitalist economies jumpstarted by foreign aid. Gerschenkron's (1962) historical perspective on economic backwardness corroborated the "Big Push" and "take-off" hypotheses with "Great Spurt" idea driven by high growth in large manufacturing and the relative neglect of agriculture.

All these ideas pointed to "capital deficit" as the central bottleneck to economic development. While this paradigm receded to the background in the waning decades of the 20th century, the associated economic ideas would resurface time and again. The modern reincarnation of the "Big Push" idea is 
47

perhaps Sachs's much debated "End of Poverty" plan for Sub-Saharan Africa (2005) via the ramping up of aid to committed levels.

In the immediate aftermath of world war II, growth theory was directed to understanding of the Western economies. The first shots were meant to understand short-run experience. Domar (1946), commenting on a business cycle issue, proposed a framework that showed the growth of GDP as a fixed proportion of the share of investment in GDP. This came to be known as the Harrod-Domar model. This was not a theory of long-run growth but it clearly incorporated the dominant stereotypes of its time. The fixed proportion technology embodied the idea of "surplus labor" with zero marginal product in the aftermath of world war II (relating to the decommissioning of military personnel). It also embodied the current understanding of the Soviet economic strides (Domar was, after all, a Russian emigré). In very simple terms, the "financing gap" is the difference in the rate of investment that a country can finance and the rate of investment that it needs to attain its desired growth rate (see Box 1). This further strengthened the claim of financing gap as a central concept in the praxis of growth promotion and aid level determination.

\section{Box 1: $\quad$ The Financing Gap}

The capital constraint framework starts with a fixed proportion production function $\mathrm{Q}=\alpha \mathrm{K}$, where $\alpha$ is the marginal (or average) product of capital, $\mathrm{K}$ is the capital stock, and $\mathrm{Q}$ is national output or gross domestic product (GDP). The implicit assumption is that the only binding constraint is capital, while other inputs are in excess supply and used in fixed proportion to capital. In per capita terms, this becomes $\mathrm{q}=\alpha \mathrm{k}$ where $\mathrm{q}=\mathrm{Q} / \mathrm{L}, \mathrm{k}=\mathrm{K} / \mathrm{L}, \mathrm{L}$ is labor. In incremental terms we have:

$$
\begin{aligned}
\Delta \mathrm{q} & =\alpha \Delta \mathrm{k} . \\
\Delta \mathrm{k} & =\mathrm{k}[(\Delta \mathrm{K} / \mathrm{K})-\mathrm{n}]
\end{aligned}
$$

where $\mathrm{n}$ is the growth rate of population. Thus, the growth rate of per capita GDP is

$$
(\Delta \mathrm{q} / \mathrm{q})=\alpha(\mathrm{I} / \mathrm{Q})-\mathrm{n}
$$

where $\mathrm{I}$ is aggregate investment. The simple aggregate income identity, $\mathrm{Q}=\mathrm{C}+\mathrm{S}$, gives aggregate savings $\mathrm{S}=\mathrm{Q}-\mathrm{C}$, where $\mathrm{C}$ is aggregate consumption. Letting aggregate savings $\mathrm{S}$ equal aggregate investment $\mathrm{I}$ and letting capital stock increment $\Delta \mathrm{k}=\mathrm{I}$ gives

$$
(\Delta \mathrm{q} / \mathrm{q})=\alpha(\mathrm{I} / \mathrm{Q})-\mathrm{n} \text {. }
$$

$\alpha$, the marginal (or average) product of capital, is also the reciprocal of the "incremental capitaloutput ratio" (ICOR). This facilitates the determination of the financing gap which is the difference between the per capita growth target of an economy and the per capita growth that it can afford.

Example: Let $\alpha=1$, and $\mathrm{n}=0.03$ or $3 \%$. Let $\mathrm{Q}=100$ and $\mathrm{I}=4$. The $(\Delta \mathrm{q} / \mathrm{q})=(\mathrm{I} / \mathrm{Q})-0.03=$ 0.01 or $1 \%$. The $1 \%$ growth in per capita GDP is the affordable level. Then at the same Q and I, we solve for the financing gap $\mathrm{F}$ for a $5 \%$ growth from $(0.05+0.03)=(\mathrm{I}+\mathrm{F}) / \mathrm{Q}$ and $(0.08) \mathrm{Q}-\mathrm{I}$ $=\mathrm{F}$ or $\mathrm{F}=4$ or $4 \%$ of GDP. In general, the simple financing gap formula is:

$$
\mathrm{F}=[(\Delta \mathrm{q} / \mathrm{q})+\mathrm{n}](\mathrm{Q} / \alpha)-\mathrm{I} \text {. }
$$


Lewis (1954) customized the Harrod-Domar-Kovalevsky model for third world countries, based on the premise of "rural surplus labor" that made capital the only binding constraint, thus allowing fixed proportion technology. "Capital accumulation is economic development" may well be the principal mantra of that development era. The Lewis dualistic labor-surplus economy was formalized by Ranis and Fei (1964) in what came to be known as the Ranis-Fei-Lewis model.

It is no surprise that growth-promoting and aid-allocating agencies would gravitate toward capital constraint models of growth. The prevailing view was that aid is the pivotal ingredient for growth and development, and aid agencies may spell the difference between growth and stagnation. On hindsight, this mechanical view was very naïve, but at that time it was not yet known that growth had, in fact, not only to do with resource or capital constraint but everything to do with policies, institutions, governance, and even cultural factors. These issues, however, still lay outside the purview of orthodox economics (Landes, 1990).

The Harrod-Domar-Kovalevsky model envisioned only one aggregate gap - the Savings-Investment gap. In economies with fully convertible currencies, this should be sufficient since aggregate domestic savings will just as easily pay for domestic as well as foreign procurements. The national income identity $\mathrm{Y}=\mathrm{C}+\mathrm{I}+(\mathrm{M}-\mathrm{X})$ sees to this. Where $\mathrm{Y}$ is national income, $\mathrm{C}$ is consumption, $\mathrm{I}$ is investment, $\mathrm{M}$ is imports, and $\mathrm{X}$ is exports.

( $\mathrm{Y}-\mathrm{C})$ pays for I as well as $(\mathrm{M}-\mathrm{X})$. In a world of nonconvertibility, domestic surplus may not procure foreign goods for investment and consumption. Non-convertibility was a common ailment among third world countries in the Bretton Woods era of fixed exchange rates and import substitution. This gave rise to "two-gap models" (see Box 2). Chenery and Strout (1966) identified them as the "resource gap" and the "foreign exchange gap".

While the two-gap model treated private and fiscal resources as fully convertible, this may not be the case. Distortions in the domestic financial market may prevent the government from accessing private surplus. Thus, the fiscal deficit may not be financed by domestic borrowing alone. This raised the need to separately treat the fiscal gap from the domestic resource gap. Thus, the three-gap model made its appearance. The World Bank's Financial Programming Model (Taylor, 1990; Ranaweera, 2003) uses an elaborate three-gap model. 
Box 2: Gap Models

\begin{abstract}
One Gap: Resource Gap
In the ideal world of completely convertible currency, the single gap envisioned in the Smith-Harrod-Domar-Kovalevsky model is the resource gap RG, and the national income identity determines it to be:

$$
R G=(Y-C)+(T-G)-I-(M-X)
$$
\end{abstract}

where $\mathrm{Y}$ is national income, $\mathrm{C}$ is consumption, $\mathrm{T}$ is taxes, $\mathrm{G}$ is government expenditures, $\mathrm{I}$ is investment, $\mathrm{M}$ is imports, and $\mathrm{X}$ is exports. Fiscal savings $(\mathrm{T}-\mathrm{G})$ and private savings ( $\mathrm{Y}$ $-\mathrm{C})$ pay for I and net imports $(\mathrm{M}-\mathrm{X})$.

\title{
Two Gaps: Resource and Foreign Exchange Gaps
}

In a world of currency non-convertibility, resource surplus may not finance imports of goods and services. Thus, $(\mathrm{Y}-\mathrm{C})+(\mathrm{T}-\mathrm{G})$ may not finance $\mathrm{I}+(\mathrm{M}-\mathrm{X})$. Even if $\mathrm{RG}=0$ in domestic currency, there is additionally a foreign exchange gap which has to be separately filled.

\section{Three Gaps: Savings-Investment, Fiscal, and Foreign Exchange Gaps}

In the two-gap model, private savings and fiscal savings are treated as fully convertible. Domestic distortions may, however, prevent private savings from being convertible to fiscal savings. In this case, the fiscal gap has to be separately treated and remedied. The cure to the gaps is clearly foreign savings coming in the form of either foreign investment, foreign loans, or foreign aid.

It is clear that distortions in the domestic, foreign exchange and financial markets underpinned the gap models. The gap approach was especially congenial to aid agencies and aid donors, partly due to the fact that these models preserve the centrality of foreign aid in the growth process (see, e.g., White, 1992). However, that the gap models continue to be the main tool of international financial institutions (IFIs) and other aid institutions in aid level determination may come as a surprise because both the Big Push and gap models only afford a mechanistic view of the growth process (Easterly, 2001).

By the early 1970s, it was clear that at least in East Asia, economic growth was becoming a sustained reality. There was, however, a widespread observation that growth was not readily translating into poverty reduction; the benefits of growth were not being shared. Not enough of the so called "trickle-down effect" was happening (Chenery et al., 1974). The problem was that in the context of Kuznets' Inverted U Hypothesis, income distribution may first worsen before it improves in the process of growth. The aid intervention was meant to improve trickle-down performance. More project lending was delivered while emphasis was somewhat shifted toward income 
distribution. Because many poor people were living in rural areas, project aid was redirected to rural areas under the guise of rural development.

It is Easterly's (2001) strong claim that the "financing gap" derived from the Domar model was and continues to rule over the multilateral development banks' mindset on development aid and financing. This wide use of financing gap models is despite the availability of less mechanical models beginning in the 1960s. The Solow model (1956) began to highlight technology as a growth engine and the subsequent Solow-based Total Factor Productivity studies suggested its critical role at least in developed economies. But technical progress remained exogenous until Romer (1986) and Lucas (1988) endogenized it. Endogenized technological change put the onus for growth on brains rather than brawn. This spawned a wide array of studies highlighting the importance of research and development (R\&D) and human capital. Primary education became the most enduring and robust argument in growth determination regressions. There was a long way from adequate resource provision to proper resource use toward technology advancement. Still and all, the pull of the financing gap argument continued in terms of aid allocation to the different impulses coming from these new understandings.

However, the most important obstacle to the reshaping of the aid architecture based on these new ideas was the choppy macroeconomic environments of the 1970s and 1980s. The 1970s witnessed the first and second oil crises which wrecked havoc on the macroeconomic and BOP fronts and put stabilization efforts in the forefront. These crises also opened a new and massive window for foreign lending, namely, the "recycled petrodollars" which lifted somewhat the burden on foreign aid by providing foreign funds at negative real interest rates, and triggered the "crisis decade" of the 1980s.

The 1980s saw a large swathe of countries stumbling into a debt crisis occasioned by heavy foreign borrowing in the previous decade and the precipitate rise in the real interest rate. This became known as the "debt crisis decade." Structural adjustment lending became a logical corollary of stabilization programs following a BOP or other crises. The occurrence themselves of BOP and other unsustainable imbalances suggested that some structural bottlenecks are to blame. These must be identified and corrected if the imbalances were to be prevented from recurring. This underpinned the World Bank's structural adjustment loans (SALs), which became the workhorse of policy-based lending in the 1980s. The SALs were designed to ease the way for reforms largely involving domestic market policies (e.g., privatization and deregulation). Structural adjustment loans were disbursed directly to the recipient's treasury but were generally attached to some future policy actions. This was usually program lending extending over several years and consisting of multiple tranches. The concept was to "push" or "buy" 
reforms (Easterly, 2003; Radelet, 2005). The performance record however fell very short of expectation.

\section{Post-Cold War Developments}

The emerging view on aid in the mid-1990s was shaped, first, by a confluence of a number of historical and political developments (see also Foster and Leavy, 2001). The second was the emergence of the development paradigm that puts "institutions" and "rule of law" at the center stage of development thinking. And the third was the emerging body of empirical evidence on the impact of aid.

\section{Historical and Political}

The collapse of the Berlin Wall and the end of the Cold War weighed very heavily on foreign aid thinking especially on the motivation behind foreign aid. The geopolitical and foreign policy motives for aid figured so much less than before, giving other goals especially altruistic ones more prominence. Growth and poverty reduction in the LDCs could finally move closer to the center of aid thinking. The more intense competition among market economies, however, also meant that the commercial motive for aid also began to figure more heavily.

The disappointing growth outcomes of the conditionality-based structural adjustment initiatives in the 1980s were becoming apparent and called for a re-examination of the aid delivery systems (Easterly, 2001). This also began to dampen the enthusiasm for the policy-first advocacy enshrined in the first generation Washington Consensus. The donors themselves began to realize that the SAL modality was not delivering the expected development impacts. One reason for the poor results appeared to be the failures of SAL reforms to create an enabling macroeconomic environment.

Along with this understanding is the recognition that the amount of aid should be large enough to spur development and growth. On one hand, as many argue, the amount of aid flows were not adequate to make the "take off" of a developing economy happen. On the other hand, aid flows were unpredictable and volatile ${ }^{4}$ so that a sustained consistent input is not assured to support a country's long term development strategy. Celasun and Walliser (2008a, 2008b) find that lack of predictability in aid flows forces government to cut investment spending during aid shortfalls and to increase consumption

\footnotetext{
${ }^{4}$ According to Celasun and Walliser (2008a), aid is predictable if recipients can be confident about the amount and timing of aid disbursements while aid is volatile if it moves up and down significantly between two time periods.
} 
spending during aid windfalls. Both consequences of aid unpredictability adversely affect long term development planning and implementation.

Not only were the outcomes of conditionality-motivated aid initiatives dismal, but the continued misery and destitution in aid-dependent Sub-Saharan Africa pointed to the futility of past interventions. While other undesirable forces (wars, ethnic unrest, etc.) were clearly at work in this region, there was also undeniable evidence that foreign aid was being massively wasted or stolen (see, e.g., Easterly, 2001).

There was also growing clamor for "participation" and inclusion, especially among the increasing number of NGOs who claim to stand for the poor and the excluded. Their voices were, in the face of failure, becoming louder and could no longer be ignored (Wolfensohn, 1997). The "Wolfensohn era" in the World Bank became a watershed for responsiveness to previously ignored aspects of the development community. There emerged a growing recognition that "poverty reduction" was being marginalized by an overemphasis on economic growth and "trickle down" effects. The emphasis fell very short of expectation and so, largely failed to deliver the "trickle down" effect on poverty (World Bank, 1998). So compelling was the view that the first decade of the 21 st century saw a new and direct assault on poverty and its correlates - the United Nation's MDGs ${ }^{5}$ which changed the rhetoric and the goals of aid-giving.

The multifarious demands of, and poor coordination among, donor agencies were being increasingly recognized as taxing the capacities of LDCs and creating incentives and a convenient cover for diffused delivery both by the donors and by the recipients. The average number of donors per country grew from about 12 in 1960 to about 33 in the 2001-2005 period (IDA, 2005). The inclusion in the game of aid giving of non-DAC and other emerging donors ${ }^{6}$ is contributing to the increased complexity of balancing various and differing priorities of donors with the needs of the recipients, not to mention the extra administrative burden imposed on recipients. The recognition of the need to improve aid delivery crystallized the urgency for more cooperation and less rivalry.

\footnotetext{
${ }^{5}$ The Millenium Development Goals, consisting of eight international development goals ranging from halving extreme poverty to developing a global partnership for development, were to be achieved by 2015 .

${ }^{6}$ These non-DAC and emerging donors include: (i) Non DAC OECD donors such as Korea, Mexico, Turkey, and several European countries; (ii) New European countries which are not members of OECD; (iii) Middle East and OPEC countries; and (iv) Non OECD countries which does not belong to any of the above groups such as India, China, and Brazil and Russia.
} 
The progress has been modest where multiple donor agencies implement their own aid programs relatively independently (Riddell, 2007). The large number of official donors and agencies involved in aid giving oftentimes leads to competition for funding particular projects or programs, often involving separate project implementation units that raise the transactions cost of aid operations. Better coordination among donor agencies - manifested of late through new aid modalities such as sector-wide approaches (SWAps) and budget support (Box 3), or through the conduct of joint programming, monitoring and evaluation missions - thus emerged as an important element of better delivery of aid.

\section{Box 3: Sector-wide Approach, Program-based Approach, and Budget} Support

A sector-wide approach (SWAp) is not a modality, but a mechanism whereby financial aid by a group of donors is earmarked to support a single sector policy reform and investment program, crafted and implemented under the recipient's leadership, and for the most part uses the recipient's own budget management systems for sector disbursement (Foster, 2000). A SWAp can include many aid modalities and its salient feature may be donor coordination.

Budget support is a method of financing a partner country's budget through a transfer of resources from an external financing agency to support a mutually-agreed national development program. Budget support operates within a medium-term framework, with annual disbursements triggered by satisfactory performance on a set of mutually-agreed and transparent indicators, either involving institutional or policy reform or development outcomes (e.g., poverty reduction). It offers the prospect of reducing transaction costs, facilitating donor coordination, and the predictability of aid flows (OECD, 2006). Budget support is also believed to enhance the country ownership. Budget support is the modality considered most in keeping with the Paris Declaration principles. It can be provided as general budget support (GBS) or sector budget support (SBS) ${ }^{7}$.

Program-based approaches (PBAs) emphasize comprehensive and coordinated planning for a given sector or thematic area of intervention under an economic and social program of the recipient country. PBAs, in general, can be viewed as an extension of SWAps and may, indeed, cover SWAps as well as projects and budget support. The main features of a PBA are flexibility and comprehensiveness in support of an integrated set of activities designed to achieve an interrelated set of results. The salient feature of the programmatic approach is its medium- to long- term engagements-mainly investments and institutional capacity building - in a sector with a coordinated set of activities for better development impacts.

Distinction among the PBA, SWAp and budget support is not easy as there are overpalling characteristics.

${ }^{7}$ The World Bank's development policy lending (DPL) and the poverty reduction strategy credit (PRSC) and the IMF's Poverty Reduction and Growth Facility (PRGF) are explicitly budget support delivery mechanisms. 
In the realm of development ideas, there emerged a new view emphasizing the central importance of institutions, rules, and enforcement. The view springs from the now widely-accepted empirical observation that the development of Western Europe closely dovetailed the emergence of market-enhancing institutions, whether state-based or voluntarily embraced, that made market exchanges less risky and more predictable (North and Thomas, 1973; North, 1990). These institutions-for example, the Maghribi and the Bank of England - provided protection for property rights and enforcement of contracts (North and Thomas, 1973; Greif, 1989). This led to the observation that development failures are close correlates of institutional failures.

The empirical support from cross-country studies came to light with the availability of governance quality indices (e.g., the Kraay-Kaufman, Freedom House, World Bank Institute) that proved statistically robust. The "institutions matter" view reached its height in the "deep determinants" debate where the consensus seems to be "policies don't matter as much as institutions" (Rodrik, 1999; Easterly and Levine, 2002; Rodrik et al., 2002). This would generate new development mantras-institutional deficit and rule of law - which would guide aid giving in the new century. This was a new and perhaps more fruitful target to train development aid upon.

Corollary to this was the growing recognition of the weak capacity of the state as conduit for aid. Weak bureaucracy, egregious waste and rampant corruption, everything that came under the rubric of "institutional failures", created the search for other conduits. The private sector has normally been viewed with suspicion by the donor community because it is by definition profit-oriented. Nonetheless, in view of the discipline of the market to which the private sector is normally accountable, resources may be better used here than in government. Easing the capital constraint facing market players may at times be a better use of aid resources than building "bridges to nowhere."

\section{Emerging Evidence}

Many of the above issues received reaffirmation from the post-Cold War empirical evidence that seemed to disagree with those of the 1980s. Results by Boone $(1994,1996)$ and White (1992) seemed to favor the null hypothesis of "no effect of aid on growth" over the judgment of inconclusive

\footnotetext{
${ }^{8}$ This is in the title of an article by D. Leigh and R. Evans in The Guardian (20 December 2005) on bridges in the Philippines financed by loans from the British Export-Import Bank.
} 
evidence of the 1980s (e.g., Mosley et al. 1987, Michalopoulos and Sukhatme 1989). Finally, the Burnside and Dollar result (1997, 2000), pointing toward effective aid conditioned on good macroeconomic environment, provided a window for how to improve outcomes and gave renewed impetus to aid effectiveness enhancement. We discuss the details of this in the next section.

\section{Aid Effectiveness}

We now survey the empirical evidence on aid effectiveness that gave impetus to the new thinking in aid giving. Measurement of broader effectiveness of aid should include longer term variables that capture growth, change in poverty, and aggregate development (Riddell, 2007). Owing to the lack of empirical findings of such broader aid effectiveness analysis our discussion is largely confined to the impact of aid on economic growth. Nonetheless, the results prove very influential in subsequent aid thinking. Note that the evidence here is based on econometric and cross-country analyses.

\section{Empirical Evidence vis-à-vis Aggregate Aid}

The longstanding aid effectiveness debate before 1990 can be characterized as unresolved. From a review of studies on the impact of aid at the country level, Riddell (2007) found that majority of these evaluations provide insufficient information from which to draw firm conclusions about aid effectiveness, which in turn influenced donors to think more strategically about their aid contributions.

Cross-country evidence on the effect of aid on growth of GDP proved largely inconclusive (Mosley et al. 1987; Michalopoulos and Sukhatme 1989). In the early 1990s, the thinking began to shift toward the claim that aid was unrelated to growth (White, 1992). It was, however, the Boone (1994, 1996) results that refocused attention. Boone found that aid had no effect whatsoever on investment and growth but it did raise the size of government. This was clearly threatening to the whole aid-giving community. Did this mean that aid recipients received no benefit at all from the aid flows? Why were there cases of spectacular aid successes?

The reassuring response came with Burnside and Dollar (1997) who showed that while the variable "(Aid/GDP)" showed no effect on growth of GDP, the interaction term "(Aid/GDP) x Policy" was positive and significant. Here "Policy" is defined as the policy index constructed by Burnside and Dollar from three policy variables (inflation, fiscal deficit, and openness). This was corroborated by Durbarry et al. (1998) and Collier and Dollar (2001). Those aid recipients who scored high in the Policy Index benefited from aid; those who scored low did not. That explained the "no-effect result" 
of Boone (1994, 1996) and the "inconclusive" evidence of the 1980s, and gave a new direction to aid giving.

While there were and still are many critics, Hansen and Tarp (2001, 2004) insist that aid positively affects growth regardless ${ }^{9}$; Easterly et al. (2004) continue to insist that "(Aid/GDP) x Policy" is not robust against data and specification changes; Rajan and Subramanian (2005) conclude that no robust evidence exists for the effect of aid on growth, including conditional aid. The aid community itself seems to have embraced the Burnside-Dollar viewpoint on intuitive grounds and on the fact that it represents a middle course between polar opposites: aid is effective conditionally and the condition is "good macroeconomic environment". The latter has become an integral underpinning of the so-called "New Aid Paradigm" and underlies the imperative of "selectivity".

\section{Empirical Evidence vis-à-vis Aid Modality}

The Burnside-Dollar view attributed aid ineffectiveness squarely on recipient dysfunction ${ }^{10}$, viz., bad macro. But that may be only part of the problem; recipient dysfunction can be compounded by donor dysfunctions. For example, the modality used to deliver aid, the quality of prior analytical work that underpins project designs, or the inappropriate conditionality associated with aid may also contribute to the problem. In this subsection we focus on the major types of aid modalities.

\section{Grants vs. Loans}

One of the lively debates on aid today is the relative effectiveness of grants versus loans (Jacquet, 2004). This was partly sparked by a proposal made by US President George Bush (July 2001) that development banks raise the share of grants in total multilateral aid up to $50 \%$. What is the evidence here? We first focus on the different impacts of grants and loans on tax revenue, tax effort, and government spending allocation.

Gupta et al. (2003) ask the question: How does LDC government revenue respond to concessional loans and grants? They find that loans are generally associated with higher government revenues while grants result in the opposite. In LDCs associated with high corruption levels, grants are

9 Although not referring in particular to aid effect on growth, Riddell (2007) concluded, after reviewing a large number of studies, that official development aid largely works.

${ }^{10}$ Recipient dysfunction, which is also an important determinant of aid effectiveness, includes poor commitment, inadequate capacity, lack of ownership, and poor governance in addition to the lack of an enabling macroeconomic environment. 
almost totally offset by revenue decline. Grants are, thus, inferior to concessional loans as a modality. Clements et al. (2004) showed that grants tend to lower tax revenue collection. In the poorest and most corrupt quartile of LDCs, tax giveaways to the tune of $95 \%$ of the grant follow the receipt of the grant. Since tax giveaways benefit the rich, grants become supplemental income to the rich. By contrast, loans tend to be accompanied by higher tax revenue. Odedokun $(2003,2004)$ found that grants tended to (i) reduce tax effort; (ii) promote inflation finance; (iii) encourage government consumption; and (iv) reduce government investment. Odedokun (2004) also found, however, that concessional loans tended to increase demand for credit and possibly promote over borrowing. Djankov et al. (2004) corroborate Odedokun on grants promoting government consumption and loans raising government investment. The message here appears to be that a grant is inferior to a concessional loan with an equivalent grant element. Concessional loans seem to induce high spending responsibility on the part of aid recipients relative to grants. Gunning (2000) believes, however, that this may not be all bad since "tax relief" financed by grants in weak governance countries can also serve growth. This view, however, is a decided minority.

Next, what is the evidence of impact of grants and loans on economic growth? Sawada et al. (2004) explored the differential effects of grants and concessional loans. They disaggregated aid into grants and concessional loans and ran ratios of these to GDP separately against growth of GDP in the standard aid-growth regressions. Their findings echo Burnside and Dollar (1997): (i) neither unconditioned grants nor loans affect growth; and (ii) loans conditioned on good macroeconomic policies promote growth but grants so conditioned do not. The message is consistent with the Clements et al. (2004), Odedokun (2004) and the Djankov et al. (2004) results since good macro tends to be partly induced by loans.

Cordella and Ulku (2004) constructed the "degree of concessionality" variable "(EDA/ODA)" where EDA is the effective development assistance or the sum of grants and grant equivalent of loans, and ODA is the sum of grants and loans on concessional terms (i.e., of at least $25 \%$ of face value), and added this as an independent variable in the standard aid-growth regressions. They found statistically insignificant effect on economic growth regardless of specifications. Thus, more grant share has no effect on growth. They also interacted the degree of concessionality with proxies for country characteristics (poor, badly governed, highly indebted), the hypothesis being that grants do well for these types of countries. They found that the interacted variable "(EDA/ODA) x Proxies" is positive and significant for growth.

Nunnenkamp et al. (2005) retreated from standard aid-growth regression analysis to do a simple correlation analysis to differentiate between 
grants and loans. They used a sample of 30 and 60 poorest countries to avoid reverse causality (donors tend to give more to poorer recipients which is a confirmed fact; see, e.g., Canavire et al., 2005). The dependent variable is average per capita gross national income (GNI) in subsequent 5 years (to give aid room to affect growth in longer term). Their results are: (i) total net loan is positively correlated with growth for the 60-country sample; (ii) the nonparametric Spearman correlation shows a negative link between aid and growth for the poorest 30 -country sample but not for the 60-country sample; and (iii) for the 30-country sample, the negative effect is stronger for grants than for loans. From this study, it is not clear that loans are superior to grants. Note, however, that no controls were employed, so the robustness of the results is suspect.

Operationally, grants and loans work somewhat differently. Grants are generally administered by the development agencies and they have better control over utilization of them. Grant money is mostly used for technical assistance projects which undertake variety of analytical work for project preparation and policy and institutional reforms. The causal relationship between the grant resources and national income or economic growth is therefore can be murky. Resources provided under the loans are generally utilized for infrastructure and other investment activities. This may partially explain the positive and negative impacts of loan and grants, respectively on the national income.

Overall, the weight of evidence on Grants vs. Loans clearly appears to lean in favor of Loans being more effective. There is, however, some evidence that for the poorest countries, grants as relief for the debt overhang helps growth. The role of grants in heavily indebted countries is to ease the debt overhang which in the first place erases any growth. Some growth follows the removal of the "sword of Damocles" of debt.

\section{Project Aid vs. Budget Support}

Another interesting divide in the aid modality arena is project aid vs. budget support. ${ }^{11}$ Project aid was the workhorse of foreign aid since the beginning of the foreign aid era in the 1950s, which largely relied on parallel systems to ensure spending the aid money for earmarked activities. Budget support is a more flexible modality that supports the implementation of the

11 In contrast to the flexibilities imbedded in budget support, project aid is characterized by heavy donor control. Earmarking at its starkest comes in project aid. Generally the project aid is implemented with parallel management and disbursement systems created for the project. New variants of project aid sometimes use government systems or NGOs. 
59

national development plan of the recipient country using existing government systems together with ex post conditionality. Budget support is believed to help harness country ownership and dispose of the concept of "buying policy and institutional reforms" through ex ante conditionality. Which is more effective for growth?

Cordella and Dell'Ariccia (2003) decomposed aid into project aid and budget support and added the ratios of these to GDP into the standard aidgrowth regression following Burnside and Dollar (1997). Apart from replicating Burnside and Dollar results for a slightly different specification and aid data, they showed that (i) neither unconditioned budget support nor project aid affects growth; (ii) budget support conditioned on good macro policies is positive and significant for growth; (iii) project aid conditioned on good macro policies is negative and significant for growth.

The message is straightforward: Budget support has a potential for advancing growth when given to countries with good existing macro policies or countries which undertook meaningful policy and institutional reforms toward this end. The reason for this is simple: under good macroeconomic conditions, budget support is able to exploit the benefits of synergy and scale economies as well as the auxiliary benefit of improving institutional capacity and partnership. Local ownership may also be stronger when existing systems are used to deliver aid and aid comes as reward for reforms already undertaken by the recipient country. Again, selectivity in favor of good macroeconomic environment is strongly supported; but more importantly, good macroeconomics makes good partner with budget support but not with project aid. This is not to say that bad macroeconomics will partner well with project aid.

\section{Bilateral Aid vs. Multilateral Aid}

Foreign aid comes as either: (i) bilateral aid, or (ii) multilateral aid. Bilateral aid is largely grants while multilateral aid is a combination of grants and loans. According to the general trend of aid disbursements, about $70 \%$ of the ODA flows have been provided by bilateral organizations and the rest is channeled through multilateral organizations (IDA, 2007). Ram (2003) showed evidence that bilateral aid affects growth positively while multilateral aid is negative for growth. Headey (2005), by contrast, found that multilateral aid was more effective at advancing growth than bilateral aid in the pre-1990 sample but the reverse is true for the post-1990 sample. The explanation offered is that bilateral aid in the pre-1990 sample was motivated by nonaltruistic geopolitical goals, which was effectively replaced by altruistic global public goods motives after 1990. The pooling of the two-period sample will show no effect of bilateral aid on growth. Rajan and Subramanian (2005) 
60

addressed most major issues in the aid literature. Their sweeping econometric analysis found no differential effects between bilateral and multilateral aid. The evidence here can best be characterized as inconclusive.

\section{Tied Aid vs. Untied Aid}

Miguel-Florenza (2006) ran tied aid and untied aid separately in the standard aid-growth regressions following Easterly et al. (2004). He found that tied aid is negative and significant against growth. This result, however, is not sustained with the use of different samples. Untied aid does better under good macro. That untied aid does better than tied aid supports the Cordella and Dell'Ariccia (2003) result on the superiority of budget support. The problem here is that, in practice, it is difficult to find aid that is purely untied.

\section{Development Aid vs. Geopolitical Aid}

As observed earlier, aid can be driven by various motives on the side of the donor. These conflicting motives can affect the modalities that aid takes and exhibit different effects on the favored public good metric, viz., growth. Following Headey (2005), Minoiu and Reddy (2006) explored the differential effects on growth of two important aid types: development aid and geopolitical aid. Development aid involves aid for infrastructure, education, health, etc., that is expected to impact growth positively. It is geopolitical, otherwise. However, data on the destination of aid is spotty. Proxies, of greater or less plausibility, are based instead on origination (donor type). Using various origination proxies, they found that development aid has a positive and significant effect on long-term growth in standard aid-growth regressions. Geopolitical aid exhibited zero or negative effect.

The lesson here, if taken with caution, is that altruistically motivated aid directed toward growth-enhancing projects can advance the long-term economic position of recipients. Thus, the motives for aid giving matter. The quality of aid delivery also matters as the next section will show.

\section{Donor and Recipient Dysfunctions}

A successful aid program requires matching elements of (i) sound development strategy, (ii) appropriate aid strategy supported by well-designed projects or programs backed by sound prior analytical work, and (iii) effective implementation. Because donors and recipients are jointly responsible for all three elements, donor-recipient partnership is critical for aid effectiveness. Failures in any of the above three elements are generally considered as donor and recipient dysfunctions, which are largely interdependent. Both have the ability to influence each other although the degree of influence is tilted more 
61

toward donors. Moreover, the degree of responsibility varies from attribute to attribute. For example, the preparation of a sound development strategy is mainly the responsibility of the recipient country whereas the donors have the opportunity to influence it. On the other hand, design of projects/program is generally undertaken by donors with various levels of inputs from recipients. In this section we discuss certain aspects of donor and recipient dysfunctions.

The evidence here shows that donor dysfunctions such as loan pushing, defensive lending, absence of intensive policy dialogue, poor preparatory analytical work, absence of proper and timely supervision, and lack of effort at engendering partnership reduce the probability of success of aid operations in promoting economic development. At the same time, recipient dysfunctions characterized by lack of commitment, lack of ownership, lack of an enabling policy and institutional framework, deficiency in capacity to administer and implement aid operations, poor governance, macroeconomic instability, political unrest, corruption that diverts aid from its intended purpose also contribute to the failure of an aid operation, and thus, constrain aid effectiveness.

From the donors end, the circumstances surrounding how aid is delivered can also matter for the success or failure of the aid operation. Delivery here involves, on one hand, the prior analysis to determine the timing, appropriateness, and criticality of aid, and on the other hand, the extent of policy dialogue and involvement of the recipient to ensure ownership and mutual accountability for the project. When the incentive structure rewards only the total volume of funds disbursed or when a loan is intended to keep the recipient from defaulting, then these prior works will be neglected. What is the evidence?

Birdsall et al. (2003) showed evidence of "defensive lending", that is providing further loans to indebted recipients to forestall a default on past loans. Defensive lending makes loans available even when such loans are inappropriate. Defensive lending is motivated no longer by altruism but by self-interest. It, thus, exemplifies donor dysfunction.

Donors may influence the outcome of an aid operation by affecting important variables within their control such as prior analytical economic and sector work (ESW), timing and intensity of project supervision, and even policy dialogue. Proper selectivity, i.e., extending aid to countries that are in the position to benefit or funding projects that are critical or of high impact can improve the performance of an aid or loan portfolio. While the studies cited here largely use World Bank data on performance evaluation, insights are especially useful for all aid agencies. 
62

(i) Deininger et al. (1998) showed that intensive preparatory analytical work (called ESW) on what is appropriate, what is adequate in amount, what is the proper timing, etc., significantly improves the quality or performance of the lending portfolio of the World Bank.

(ii) Kilby (2000) followed this up with evidence that the timing and intensity of supervision also improves the probability of success of World Bank projects.

(iii) Wane (2004) ran standard probit regressions with World Bank projects" "probability of success", constructed from project assessment by its own Operations Evaluation Department (OED), as dependent variable.

The following summarizes the results of the Wane regressions: (i) positive contributors: project quality at entry, quality of supervision, quality of implementation by borrower, quality of compliance by borrower, ESW by the bank; (ii) negative contributors: adjustment loan dummy, Africa dummy. The Wane results, though limited to World Bank projects, shed light on the importance of the following emerging ideas:

(i) Borrower Ownership as reflected by borrower quality of implementation and borrower quality of compliance. This implies the importance of careful prior "political economy assessment", say, of the conditions;

(ii) Donor Prudence as shown by bank supervision and ESW;

(iii) Selectivity as shown by the importance of borrower government effectiveness and borrower regulatory quality. This extends Burnside and Dollar (1997);

(iv) Partnership as shown by the importance of bank as well as borrower effort; and

(v) Incentive System which motivates borrower and development agency effort

\section{Donor Responses and the New Aid Paradigm}

The co-evolution of development-aid thoughts, empirical findings on aid effectiveness, significant changes in the development landscape, and the growing global concern that the fruits of development are not being equitably shared motivated a series of responses from the donor community starting in the mid-1990s. This section briefly discusses these responses and outlines the major challenges faced by donor agencies in aid delivery in line with the new aid paradigm. 
In 1996, the Development Assistance Committee, which proposed the International Development Goals, identified "local ownership" and "partnership" as crucial ingredients of aid delivery (OECD-DAC, 1996). In response to growing indebtedness of mainly sub-Saharan African countries, the Highly Indebted Poor Country (HIPC) Initiative for debt forgiveness was launched in 1996. The Initiative's debt-burden thresholds were adjusted downward in 1999, which enabled a broader group of countries to qualify for larger volumes of debt relief.

In the second half of the 1990s, the World Bank accepted the challenge of making aid more effective. In 1997, Wolfensohn's address at the Annual Meetings in Hong Kong, aptly titled "The Challenge of Inclusion", called for the recipient country to be at the driver's seat and not just a passenger in the development enterprise train. In 1998, the World Bank's "Assessing Aid: What Works, What Doesn't, and Why" called for a new approach to development lending. Wolfenshon's 1998 address to the World Bank Board of Governors entitled "The Other Crisis", exhorted member countries to pilot a "new development framework". The 1998 "Prebisch Lecture" at the United Nations Conference on Trade and Development (UNCTAD) given by Joseph Stiglitz proposed ownership and participation as key ingredients for effective delivery of aid for development.

In early 1999, Wolfensohn launched the World Bank's Comprehensive Development Framework as a unifying response to the emerging ideas. The framework emphasizes the interdependence of all elements of development-social, structural, human, governance, environmental, economic, and financial. It advocates: (i) a holistic long-term strategy; (ii) the country in the lead, both owning and directing the development agenda, with the World Bank and other partners each defining their support in their respective business plans; (iii) stronger partnerships among governments, donors, civil society, the private sector, and other development stakeholders in implementing the country strategy; and (iv) a transparent focus on development results to ensure better success in reducing poverty.

At the start of the new millennium, the global concern to combat poverty took center stage and was manifested in the MDGs, which were endorsed by at least 23 international organizations and 189 United Nations member states. World leaders committed to a new global partnership to reduce extreme poverty and a series of time-bound targets to 2015 .

In 2002, the donor community, through the Monterrey Consensus on Financing for Development, agreed to make concrete efforts toward the target of $0.7 \%$ of gross national income (GNI) as ODA to developing countries and 
64

$0.15-0.20 \%$ of GNI of developed countries to LDCs. Donors and partner countries agreed that more money alone is not enough to accelerate growth and poverty reduction efforts; there is a need to measure results and to demonstrate that results were achieved. Subsequently, the World Bank convened an International Roundtable on Measuring, Monitoring, and Managing for Results (2002), which gave birth to the Managing for Development Results (MfDR) initiative.

Shortly thereafter in 2003, the First High Level Forum on Aid Effectiveness in Rome identified a general framework ${ }^{12}$ for harmonization and alignment of aid work among the donor community. The framework evolved into the Paris Declaration on Aid Effectiveness, which was endorsed in 2005 by 60 partner countries and 60 donor agencies during the Second High Level Forum on Aid Effectiveness. The endorsement committed partner countries and donors to further the five core principles of country ownership, harmonization and alignment, managing for development results, and mutual accountability for the use of aid by 2010. This endorsement is also a tacit acknowledgment by donors and partner countries that "aid, done effectively, works" (Wood et al., 2008). Also in 2005, against the backdrop of the Global Call to Action against Poverty (GCAP) ${ }^{13}$, the leaders of the G8 industrialized countries pledged to further increase aid levels in support of the MDGs.

At the Second International Roundtable on Managing for Development Results in Marrakech, Morocco (2004), partner countries and bilateral and multilateral development agencies endorsed five core principles to support partner countries' efforts to manage for results: (i) focusing the dialogue on results at all phases of the development process; (ii) aligning programming, monitoring, and evaluation with results; (iii) keeping measurement and reporting simple; (iv) managing for, not by, results; and (v) using results information for learning and decision making.

The above initiatives acknowledge the development lessons from aid delivery and utilization. Together with the emerging research evidence on what makes aid more effective, these initiatives formalized a new aid paradigm ${ }^{14}$, which encompasses most of the development lessons learned over five decades of aid giving. The basic features of successful aid operation imbedded in the new aid paradigm can be summarized into the following:

12 The World Bank's Comprehensive Development Framework was influential in developing this framework.

13 The Global Call to Action against Poverty was founded in 2005 as a worldwide alliance of national coalitions of campaigns to "Make Poverty History".

${ }^{14}$ The new aid paradigm refers to a coherent view among the donor community as to what principles should govern the delivery of aid. 
holistic long-term development strategy; enabling policy (macro/sector) and institutional environment; good governance; country ownership; simplified and harmonized aid procedures; increased reliance on and alignment with government systems and procedures; mutual accountability and partnership; ex-post conditionality or selectivity; predictability of aid flows; and resultsbased management. These features are by no means exhaustive. The formula for aid effectiveness continues to evolve to respond to new challenges. However, if an aid program can successfully embrace the above principles, it is believed that aid will be effective.

As one can see, some of the above stated features of the new aid paradigm are interdependent as well as overlapping. For example, formulation as well as implementation of development strategy depends of the governance situation whereas actual impact of increase reliance on government systems may provide positive or negative results based on prevailing institutional and policy environment. Therefore, these elements should be viewed as interdependent and overlapping elements of a system. The aid modalities such as budget supports, programmatic approaches and SWAps attempt to encompass most of these elements of the new aid paradigm. The recent increases of aid that use these modalities is an encouraging sign of the donors commitment to the new aid paradigm; ODA for general budget support and sector programs have increase from $8 \%$ to $20 \%$ between 2001 and 2004 (IDA, 2007). Many donors have committed to increase the programmatic lending and in fact included specific targets of programmatic lending in their results frameworks.

Donor efforts to further consolidate the implementation of the principles of the new aid paradigm continue. For example, the action on MfDR is taking place in three broad areas: (i) strengthening country capacity to manage for results; (ii) improving the relevance and effectiveness of aid; and (iii) fostering global partnerships. The OECD/DAC-sponsored ${ }^{15}$ Managing for Development Results Capacity Scan (CAP-Scan) - an analytical framework and participatory process to assess and strengthen MfDR capacities in partner countries - is an example of the commitment to the MfDR. The World Bank, United Nations Development Program, and the Millenium Challenge Corporation (MCC) coordinate and support the CAPScan process including maintaining databases, coordinating training activities,

\footnotetext{
${ }^{15}$ With the technical and financial support of a core working group comprised of the Asian Development Bank (ADB), Canadian International Development Agency (CIDA), European Union (EU), Inter-American Development Bank (IaDB), Millennium Challenge Corporation (MCC), United Nations Development Programme (UNDP) and the World Bank.
} 
66

and working with governments and other partners. ${ }^{16}$ Similarly. the six members ${ }^{17}$ of the Multilateral Development Bank (MDB) Working Group on MfDR adopted the MDB Common Performance Assessment System (COMPAS) to provide a common ground where they may jointly report on their own performance. ${ }^{18}$ The results of the first COMPAS (2006), discussed at the Third International Roundtable on MfDR ${ }^{19}$ in Hanoi, Viet Nam (2007), provided the baseline for measuring MDB performance.

The Third High Level Forum on Aid Effectiveness in Accra, Ghana (2-4 September 2008) discussed what has been achieved in terms of implementation. As a follow-up, the United Nations convened a High Level Event on the MDGs in New York on 25 September 2008. The Doha Review Conference-or the Follow-up International Conference on Financing for Development to Review the Implementation of the Monterrey Consensuswas held in Doha, Qatar, from 29 November to 2 December 2008. These efforts accentuate the continuing commitment and drive of donors to ensure aid effectiveness.

The above discussion underscores the convergence of a unified global vision as to why aid was partially successful in the past and what needs to be done to make aid more effective. Donors have demonstrated their commitment to implement this vision through endorsement of various global and regional initiatives, the pinnacles of which are the Paris Declaration and the MDGs. Does this mean that aid will be efficiently delivered by donors and effectively utilized by recipients to harness development and the long lasting aid effectiveness debate will no longer be relevant? While the aid community deserves credit for its efforts toward effective delivery of aid, our assessment is that achieving the ultimate goal of aid effectiveness is still a challenging task. The new aid paradigm provides a sound set of principles to make aid more effective. Various donor initiatives discussed above also provide a good

16 Twenty countries have reviewed the CAP-Scan methodology and expressed interest.

17 African Development Bank, Asian Development Bank, Inter-American Development Bank, World Bank, European Bank for Reconstruction and Development, and Islamic Development Bank.

18 A similar initiative is undertaken by a group of 10 bilateral donors (Austria, Canada, Denmark, Finland, France, Netherlands, Norway, Sweden, Switzerland, and the United Kingdom) comprising the Multilateral Organizations Performance Assessment Network (MOPAN). The MOPAN aims to (i) promote a better understanding of multilateral organizations' roles and performance; (ii) improve policy dialogue with multilateral organizations; and (iii) help improe their overall performance.

19 Participated in by 45 countries, 32 development agencies, and 30 civil society and private sector partners. 
67

platform to begin the implementation of these principles. Despite these positive developments, achieving the development results on the ground still remains a daunting challenge. We briefly outline some of the main challenges ahead in the following section.

To highlight the gravity of the challenge of achieving development results let us quickly glance at the overall progress. Halfway to 2015, significant gaps still remain and it is doubtful whether MDG commitments can be achieved. The MDG Task Force Report (2008) identifies the gaps-in the areas of aid, trade, debt relief, and access to new technologies and affordable essential medicines - and recommends actions to address these gaps. Relative to the 2006 report, the 2007 COMPAS reported that MDBs have improved their efforts to better manage for results, individually and collectively, particularly in four of the seven categories of indicatorscountry capacity to manage for development results; country strategies; projects; and harmonization among development agencies-for public sector operations, but remained somewhat stable in the rest-allocation of concessional resources, institutional learning from operational experience, and results-focused human resources management.

Amongst the challenges, some are systemic and others are specific to donors and recipient countries. Amongst the systemic challenges, the difficulty in eliminating the non-developmental or strategic motives of aid giving is significant. Despite all the enthusiasm for the developmental motive of aid giving after the end of the cold war, strategic reasons still play a significant role in aid giving. For example, Riddell (2007) asserts that almost $60 \%$ of all the ODA remains tied or partially tied. He further shows that this tying increases the cost of aid by about $20 \%$ and as a result the purchasing power of aid is reduced by about $\$ 15$ billion per annum. Moreover, regardless of the vital importance of the aid supporting a long-term holistic development strategy of the recipient country, only about $\$ 38$ billion of the total ODA of over $\$ 100$ billion are directly linked to country strategy programs (Kharas, 2007). The rest goes for mainly special purposes (such as debt relief) and does not translate to the funds available for new development project of programs.

Increasing the aid volume to significant levels and ensuring predictable aid flows are imperative for achieving the results. Celasun and Walliser (2008b) find that the lack of predictability of aid flows affects the level, composition, and effectiveness of government spending. Unexpected aid shortfalls lead to cuts in investments while aid windfalls raise government 
68

consumption. On the other hand, aid volatility ${ }^{20}$ at best has not decreased; according to Hudson and Mosley (2006) aid volatility is increasing. Kharas (2008) estimates that the value of foreign aid is diminished due to aid volatility by about $15-20 \%$ of the total value of aid in recent years. Moreover, there are genuine difficulties for the donors to honor their commitments to increase aid. Global economic fluctuations, such as the 2008 financial crisis is a live example. Donors while facing difficult economic situations in their own countries may find it difficult to convince the tax payers to donate money for the development of poor countries.

A successful aid operation depends not only on donor efforts but also on recipient efforts to minimize recipient dysfunctions. While donors have some influence over reducing recipient dysfunctions, an immense amount of ground work needs to be done by recipient governments to strengthen institutional capacity and improve governance. It is well understood today that the development process is about people making decisions, striking bargains, and seeking the best arrangement for themselves and their groupsometimes to the detriment of the welfare of other groups and of the whole community. The political economy that enables such dynamic responses to aid has evolved over time, and changing adaptive responses of government agency personnel, at best, is not easy. Prevalence of information asymmetries between donors and recipients makes this task more difficult. While the recipient's commitment for creating good governance is vital, self governance by agencies - against their own personal vested interests - require innovative changes in the entire institutional culture of government systems.

Added to the above-discussed systemic difficulties are the difficulties encountered by donor agencies to implement the principles of new aid paradigm. The donor agencies need to put additional efforts and undergo institutional changes to fully implement the principles of the new aid paradigm. Here we outline some of the major difficulties:

(i) Donor Harmonization: Despite being a sound idea at the outset, donor harmonization is a difficult task in practice. As de Renzio et al. (2005) assert, "there is a perceived lack of clear policies and guidelines for staff to follow if, when and how to engage in harmonisation activities." Donor procedures, aid modalities, and delivery mechanisms have evolved over the years, contributing to donor identities. As donor harmonization requires drastic changes in the internal institutional structures, practices, and staff incentives, it may lead to changes in donor identities to some

${ }^{20}$ See, for example, empirical studies on aid volatility by Bulir and Hamann (2003), Fielding and Mavrotas (2005, 2007) and Chauvet and Guillaumont (2008). 
degree; and within donor agencies there would be bureaucratic reluctance for such changes. For example, Van de Walle (2005) attributes the remarkably little progress in donor cooperation to the bureaucratic resistance within donor agencies. Kharas (2007) raises the issue that the "mechanisms for information sharing, coordination, planning and aid administration are increasingly costly and ineffective," therefore constraining the pace of harmonization.

The tension between donor cooperation and donor competition is a practical reality despite the laudable commitments for cooperation. There were instances where, on one hand, a number of donors jointly agreed on a set of policy and institutional reforms to provide support for a development plan of a country and, on the other hand, a nontraditional donor capitalizing on the government's reluctance to implement politically painful reforms provides aid without any conditions. Such non-cooperative and competitive behaviors are not isolated incidents; they can be explained using the non-cooperative game theory.

(ii) Policy Dialogue and Advice: Capacities to undertake prior analytical work and provide sound policy advice vary from donor to donor. In particular, the nontraditional bilateral donors have limited or no capacity to engage the recipients in productive policy dialogue. Even amongst well established multilateral donors, aid decisions are frequently made without sufficient knowledge (Conyers and Mellors, 2005) and there are widespread information failures between donors and recipients in relation to policy and institutional reforms. In addition to the less than perfect policy analyses, some advice given by donors are not well received by many governments (Riddell, 2007), partly due to bad previous experience associated with policy advice such as structural adjustments. In a rapidly changing global economic environment, policy advice has become a difficult task and a major shift in donor - recipient cooperation and staff resource allocation to facilitate the policy support may be required.

(iii) Country Ownership and Alignment with Government Policies/Programs: Alignment with available country procedures is expected to help improve country ownership. However, to ensure aid effectiveness, donor prudence is a must in using country systems selectively. In an environment of internal pressure to deliver more aid to meet portfolio targets, suitability of existing country systems may be overlooked. Guarding against such tendencies is challenging as it requires donors to modify 
their internal performance evaluation systems toward giving more emphasis to development impact indicators rather than input indicators. Institutionalizing a staff reward system linked to development impacts is constrained by many factors and the time lag between aid delivery and development results is noteworthy difficulty

(iv) Mutual Accountability and Partnership: Developing the partnership between donors and recipients is not an easy task given the historical asymmetry of power between donors and recipients. Mutual trust and equity-based partnerships are exceptions rather than rules in many aid relationships, particularly in the poorest countries. Institutional culture and incentive structure of donors have to be changed to achieve these. When aid does not work, attributing the causal factors between donor and recipient is impractical. The current system does not make donors sufficiently accountable for development outcomes; loan repayments are guaranteed despite the success or failure of aid interventions. Lack of emphasis on supervision of project implementation in comparison to that of projects preparation and approval reflect the existing incentive system. A major change in incentive structure and re-alignment of staff resources toward this end require significant efforts within donor agencies.

(v) Ex-post Conditionality and Programmatic Approaches: While there is some evidence to suggest that budget support fares better than project-oriented aid under good macro environments, overall evidence of superiority of budget support is sketchy. Therefore, ex-post conditionality and budget support modalities are to some extent at the trial and error stage. Evidence on overall impacts of a larger portfolio of programmatic type lending is yet to emerge. A related danger is the non-selective application such lending modalities to countries where enabling environments and capacity are lacking, especially when donors are under internal pressure for disbursement of funds. From the recipient dysfunction point of view a government with poor governance record and vested interests may view ex-post conditionality and budget support as opportunities for furthering their own vested interests. To what extent donors apply selectivity will eventually determine the success of the programmatic new approach.

(vi) Good Governance: Governance is an all-embracing concept deployed to encompass everything good or bad with the state and society. There is no harmonized approach to address governance 
71

issues; different donors use different definitions (Riddell, 2007). Good governance involves financial sector reforms to human rights promotion to building the government machinery (taxation, rule of law, development planning, elections) to democratic reforms. The indicators of good governance such as transparency, political accountability, participation, effective rule of law, and enhanced information flow among different segments of society are results of a social evolution process and there is limited knowledge as to how one could intervene to reach these targets. While good governance is imperative, both donors and recipients are in search for answers to which type of poor governance contributes to what type of failures, and how weak governance should be addressed (Riddell, 2007).

As discussed above, the donor community has correctly recognized what needs to be done to make aid more effective. There are important steps between the diagnostics and the cure and these steps are constrained by many factors, both at donors and recipients ends. At the donors end acceptance of the new aid paradigm at strategic levels is necessary but not sufficient to achieve results. As Riddell (2007) pointed out, internal dynamics of how aid agencies work shows that drastic changes in the incentive system - which derive and reward agency staff and influence the front-line decisions which ultimately determine aid effectiveness - are required if aid agencies to honor their commitments for the new aid paradigm.

\section{Concluding Remarks}

This paper reviews the literature on the co-evolution of development thoughts and aid giving, and empirical findings on aid effectiveness. The review points to emergence of a new set of principles that unifies the donors view as to what makes aid more effective. The paper shows that over the last 60 years, the development priorities of donor agencies and countries evolved - either reflecting new development thinking, responding to changes in the development landscape, or in response to empirical findings on aid effectiveness. The co-evolution of development and aid ideas, guided by emerging evidence, has reached its current understanding in the new aid paradigm. This coherent view developed based on the well documented lessons and empirical evidence is largely knowledge-based. To the credit of the major donors, they are instrumental in articulating as well as institutionalizing the new aid paradigm. Donors seem confident in asserting why aid was partially successful in the past and how aid can be made more effective in the future. However, the bridging the gap between the rhetorical commitments and the actual changes required to achieve development results both at the donors' and recipients' end is challenging. How donors and 
recipients handle the major challenges in implementing the principles of new aid paradigm will determine the success of the aid in coming decades.

\section{References}

Azam, J.P. and J.J. Laffont. (2003). Contracting for Aid. Journal of Development Economics, 70(1):25-58.

Birdsall, N., S. Claessens, and I. Diwan (2003). Policy Selectivity Foregone: Debt and Donor Behavior in Africa. World Bank Economic Review, 17(3):409-435.

Boone, P. (1994). The Impact of Foreign Aid on Savings and Growth. Mimeo: London School of Economics.

Boone, P. (1996). Politics and the Effectiveness of Foreign Aid. European Economic Review, 40:289-329.

Bulir, A., and A.J. Hamann (2003). Aid Volatility: An Empirical Assessment. IMF Staff Paper, 50(1).

Burnside, C. and D. Dollar (1997). Aid, Policies, and Growth. Policy Research Working Paper 1777. World Bank, Washington DC. $<\mathrm{http}$ ://www.worldbank.org/html/dec/Publications/Workpapers/WPS1700 series/wps1777/wps1777.pdf>

Burnside, C. and D. Dollar (2000). Aid, Policies, and Growth. American Economic Review, 90(4):847-868.

Canavire, G., P. Nunnenkamp, R. Thiele, and L. Triveño (2005). Assessing the Allocation of Aid: Developmental Concerns and the Self-Interest of Donors. Kiel Working Papers 1253, Institute for World Economics, Kiel.

Celasun, O., and J. Walliser (2008a). Managing Aid Surprises. Finance and Development, 45(3).

Celasun, O., and J. Walliser (2008b). Predictability of Aid: Do Fickle Donors Undermine Aid Effectiveness? Economic Policy, 23(55):545-594.

Chauvet, L., and P. Guillaumont (2008). Aid, Volatility and Growth Again: When Aid Volatility Matters and When It Does Not. UNU-WIDER Research Paper No. 2008/78. 
Chenery, H.B. and A.M. Strout (1966). Foreign Assistance and Economic Development. American Economic Review, 56:697-733.

Chenery, H.B., M.S. Ahluwalia, C.L.G. Bell, J.H. Duloy, and R. Jolly (1974). Redistribution with Growth: Policies to Improve Income Distribution in Developing Countries in the Context of Economic Growth. London and New York: Oxford University Press for the World Bank and the Institute of Development Studies, University of Sussex.

Clements, B., S. Gupta, A. Pivovarsky, and E.R. Tiongson (2004). Foreign Aid: Grants versus Loans. Finance and Development, 46-49. Viewed September, $\quad<$ http://www.imf.org/external/pubs/ft/fandd/2004/09/pdf/ clements.pdf>

Collier, P. and D. Dollar (2001). Can the World Cut Poverty in Half? How Policy Reform and Effective Aid Can Meet International Development Goals. World Development, 29(11):1787-1802.

Conyers, D. and R. Mellors (2005). Aid Ineffectiveness in Sub-Saharan Africa: The Problem of Donor Capacity. IDS Bulletin, 36(3):83-89.

Cordella, T. and G. Dell'Ariccia (2003). Budget Support versus Project Aid. IMF WP/03/88. International Monetary Fund, Washington DC. $<$ http://www.imf.org/external/pubs/ft/wp/2003/wp0388.pdf $>$

Cordella, T. and H. Ulku (2004). Grants Versus Loans. IMF Working Paper No. WP/04/161. International Monetary Fund, Washington DC. $<$ http://www.imf.org/external/pubs/ft/wp/2004/wp04161.pdf>

Deininger, K., L. Squire, and S. Basu (1998). Does Economic Analysis Improve the Quality of Foreign Assistance? The World Bank Economic Review, 12(3):385-418. <http://www.worldbank.org/research/ journals/wber/revsep98/pdf/article\%202.pdf>

De Renzio, P., D. Booth, A. Rogerson and Z. Curran (2005). Incentives for Harmonisation and Alignment in Aid Agencies. A Report to the DAC Working Party on Aid Effectiveness. London: Overseas Development Institute.

Djankov, S., J.G. Montalvo, and M. Reynal-Querol (2004). Helping the Poor with Foreign Aid: The Grants vs. Loans Debate. World Bank, Washington DC. 
Domar, E. (1946). Capital Expansion, Rate of Growth and Employment. Econometrica, 14:137-147.

Durbarry, R., N. Gemmell, and D. Greenaway (1998). New Evidence on the Impact of Foreign Aid on Economic Growth. CREDIT Research Paper 98/8, Centre for Research in Economic Development and International Trade. University of Nottingham. <https://www.nottingham.ac.uk/ economics/credit/research/papers/cp.98.8.pdf $>$

Easterly, W. (2001). The Elusive Quest for Growth: Economists' Adventure and Misadventures in the Tropics. Cambridge: The MIT Press.

Easterly, W. (2003). Can Foreign Aid Buy Growth? Journal of Economic Perspectives, 17(3):23-48. <http://www.nyu.edu/fas/institute/ dri/Easterly/File/EasterlyJEP03.pdf>

Easterly, W. (2005). What Did Structural Adjustment Adjust? The Association of Policies and Growth with Repeated IMF and World Bank Adjustment Loans. Journal of Development Economics, 76(1):1-22. Elsevier. <http://www.listweb.bilkent.edu.tr/bsb/Easterly.pdf>

Easterly, W. and R. Levine (2002). Tropics, Germs and Crops: How Endowments Influence Economic Development. NBER Working Paper 9106. National Bureau of Economic Research. <http://www.saisjhu.edu/fukuyama/articles/Easterly.pdf $>$

Easterly, W., R. Levine, and D. Roodman (2004). New Data, New Doubts: A Comment on Burnside and Dollar's 'Aid, Policies, and Growth'. American Economic Review, 94(3):774-780.

Fielding, D. and G. Mavrotas (2005). The Volatility of Aid. UN-WIDER Discussion Paper No. 2005/06.

Fielding, D. and G. Mavrotas (2007). Aid Volatility and Donor-Recipient Characteristics in Difficult Partnership Countries. Economica, 75(299):481-494.

Foster, M. (2000). New Approaches to Development Co-operation: What can we Learn from Experience with Implementing Sector Wide Approaches? Working paper 140,Overseas Development Institute, London.

Foster, M. and J. Leavy (2001). The Choice of Financial Aid Instruments. Centre for Aid and Public Expenditure Working Paper 158. Overseas 
Development Institute, London. <http://www.odi.org.uk/ publications/wp158.pdf $>$

Geginat, C. and A. Kraay (2007). Does IDA Engage in Defensive Lending? World Bank Policy Research Working Paper No. 4328.

Gerschenkron, A. (1962). Economic Backwardness in Historical Perspective. Cambridge: Harvard University Press.

Greif, A. (1989). Reputation and Coalitions in Medieval Trade: Evidence on the Maghribi Traders. Journal of Economic History, 49 (December):852882. <http://www.jstor.org/view/00220507/di975689/97p0075n/0>

Gunning, J.W. (2000). Rethinking Aid. In Annual World Bank Conference on Development Economics. B. Plescovic and N. Stern (eds.) World Bank, Washington DC.

Gupta, S., B. Clements, A. Pivovarsky, and E.R. Tiongson (2003). Foreign Aid and Revenue Response: Does the Composition of Aid Matter? IMF Working Paper 03/176. International Monetary Fund, Washington DC. $<\mathrm{http} / / / \mathrm{www}$.wider.unu.edu/conference/conference-2003-3/conference2003-3-papers/Gupta-clements-pivovarsky-tiongson-0808.pdf>

Hansen, H. and F. Tarp (2001). Aid and Growth Regressions. Journal of Development Economics, 64(2):547-570.

Hansen, H. and F. Tarp (2004). Aid and Growth Regressions. In Foreign Aid in the New Global Economy. P. Burnell and O. Morrissey (eds.). An Elgar Reference Collection. Edward Elgar.

Headey, D. (2005). Foreign Aid and Foreign Policy: How Donors Undermine the Effectiveness of Development Assistance. CEPA Working Paper 05, School of Economics, University of Queensland, Australia.

Hirschman, A. (1958). The Strategy of Economic Development. New Haven CT: Yale University Press.

Hudson, J. and P. Mosley (2006). Aid Volatility, Policy and Development. Paper presented to the WIDER Conference on Aid, Helsinki.

IDA (2007). Aid Architecture: An Overview of the Main Trends in Official Development Assistance Flows. Paper presented at the first meeting of the IDA15 Replenishment negotiations, Paris. 
Jacquet, P. (2004). Loans or Grants? The Full Debate. Transcript prepared for the Panel at the Center for Global Development, 1 October, Washington DC. $\quad<$ http://www.cgdev.org/doc/event\%20docs/10.1.04\%20GorL/ grants\%20and $\% 201$ oans $\% 20$ transcript.pdf $>$

Kanbur, R. and T. Sandler (1999). The Future of Development Assistance: Common Pools and International Public Goods. ODC Policy Essay 25. Overseas Development Council, London. $<$ http://www.arts.cornell.edu/poverty/kanbur/Future\%20of\%20Developm ent $\% 20$ Assistance.pdf $>$

Kharas, H. (2007). Trends and Issues in Development Aid. Wolfensohn Center for Development Working Paper No. 1.

Kharas, H. (2008). Measuring the Cost of Aid Volatility. Wolfensohn Center for Development Working Paper No. 3.

Klein, M. and T. Harford (2005). The Market for Aid. International Finance Corporation, Washington DC.

Kilby, C. (2000). Supervision and Performance: The Case of World Bank Projects. Journal of Development Economics, 62:233-259.

Landes, D. (1990). The Wealth and Poverty of Nations: Why Some are So Rich and Some So Poor. New York: WW Norton \& Co.

Lavergne, R. and A. Alba (2003). CIDA Primer on Program-Based Approaches. Working Paper. CIDA Analysis and Research Division, Policy Branch. Canadian International Development Agency (CIDA). $<$ http://www.acdi-cida.gc.ca/INET/IMAGES.NSF/vLUImages/ CapacityDevelopment2/\$file/Program\%20Based\%20Approaches-E.pdf $>$

Leibenstein, H. (1957). Economic Backwardness and Economic Growth: Studies in the Theory of Economic Development. New York: John Wiley $\&$ Sons, Inc. $<$ http://www.questia.com/PM.qst?a $=$ o\&d=6472472>

Lerrick, A. and A.H. Meltzer (2002). Grants: A Better Way to Deliver Aid. Quarterly International Economics Report, January. Carnegie Mellon Gailliot Center for Public Policy, Pittsburgh. $<$ http://www.house.gov/jec/imf/grant.pdf $>$

Lewis, W.A. (1954). Economic Development with Unlimited Supplies of Labor. The Manchester School 1-32. $<$ http://www.unc.edu/ wwolford/Geography160/368lewistable.pdf $>$ 
Lucas, R., Jr. (1988). On the Mechanics of Economic Development. Journal of Monetary Economics, 22(1):3-42.

MDG Task Force (2008). Delivering on the Global Partnership for Achieving the Millenium Development Goals. United Nations.

Millennium Challenge Corporation (MCC) (2004). Guidance for Developing Proposals for Millennium Challenge Account Assistance in Fiscal Year 2004. Washington, DC. <http://usinfo.state.gov/xarchives/ display.html? $\mathrm{p}=$ washfile-english $\& \mathrm{y}=2004 \& \mathrm{~m}=$ May $\& \mathrm{x}=$ 20040504110109AKllennoCcM0.688656\&t=livefeeds/wf-latest.html $>$

Michalopoulos, C. and V. Sukhatme (1989). The Impact of Development Assistance: Review of the Quantitative Evidence. In Aid and Development, A.O. Krueger (ed.) Baltimore MD: Johns Hopkins University Press.

Miguel-Florensa, J. (2006). Aid Donors, Multiple Projects and Optimal Incentives. Department of Economics, Columbia University, New York City.

Minoiu, C. and S. Reddy (2006). Aid Matters: Revisiting the Relationship Between Aid and Growth. Department of Economics and Social Affairs Working Paper, United Nations, New York.

Nelson, R. (1956). A Theory of Low-Level Equilibrium Trap in Underdeveloped Economies. American Economic Review, 46(5):894-908.

North, D. (1990). Institutions, Institutional Change and Economic Performance. Cambridge: Cambridge University Press.

North, D. and R.P. Thomas (1973). The Rise of the Western World: A New Economic History. Cambridge: Cambridge University Press. $<$ http://www.economics.uci.edu/ dbell/North.pdf $>$

Nurkse, R. (1953). Problems of Capital Formation in Underdeveloped Economies. New York: Oxford University Press.

Nunnenkamp, P., R. Thiele, and T. Wilfer (2005). Grants Versus Loans: Much Ado About (Almost) Nothing. Kiel Economic Policy Papers 4. Kiel Institute for World Economics. <http://www.unikiel.de/ifw/pub/kepp/2005/kepp04.htm> 
Odedokun, M. (2003). Economics and Politics of Official Loans versus Grants: Panoramic Issues and Empirical Evidence. WIDER Discussion Paper WPD 2003/04, UNU World Institute for Development Economics Research, Helsinki. <http://www.wider.unu.edu/publications/ dps/dps2003/dp2003-04.pdf>

Odedokun, M. (2004). Multilateral and Bilateral Loans versus Grants: Issues and Evidence. World Economy, 27(2):239-263.

OECD-DAC (1996). Shaping the 21st Century: The Contribution of Development Co-operation. Paris: OECD. $<\mathrm{http}$ ://www.oecd.org/dataoecd/23/35/2508761.pdf $>$

OECD-DAC (2005). The Paris Declaration on Aid Effectiveness. Paris: OECD. <http://www.oecd.org/dataoecd/11/41/34428351.pdf>

OECD-DAC (2006). Harmonising Donor Practices for Effective Aid Delivery, Volume 2: Budget Support, Sector Wide Approaches and Capacity Development in Public Financial Management. DAC Guidelines and Reference Series. Paris: OECD. <http://www.oecd.org/ dataoecd/53/7/34583142.pdf>

OECD-DAC (2008). Effective Aid by 2010? What it Will Take. Vol. 1 Overview. Working Party on Aid Effectiveness. Paris: OECD.

OECD-DAC. DAC's Glossary. <http://www.oecd.org/glossary/ 0,3414,en_2649_33721_1965693_1_1_1_1,00.html>

Radelet, S. (2005). From Pushing Reforms to Pulling Reforms: The Role of Challenge Programs in Foreign Aid Policy. Working Paper \#53, Center for Global Development. <http://www.cgdev.org/content/ publications/detail/2735>

Rajan, R. and A. Subramanian (2005). Aid and Growth: What Does the Evidence Really Show. IMF Working Paper 05/127, International Monetary Fund, Washington DC. <http://www.imf.org/external/pubs/ $\mathrm{ft} / \mathrm{wp} / 2005 / \mathrm{wp} 05127 . \mathrm{pdf}>$

Ram, R. (2003). Roles of Bilateral and Multilateral Aid in Economic Growth of Developing Countries. Kyklos, 56(1):95-110.

Ranaweera, T. (2003). Foreign Aid, Conditionality and Ghost of the Financing Gap: A Forgotten Aspect of the Aid Debate. World Bank Policy Research Working Paper 3019, Washington DC. <http://www- 
79

wds.worldbank.org/external/default/WDSContentServer/IW3P/IB/2003/0 9/06/000094946_03042204042890/additional/111511322_200411171645 24.pdf $>$

Ranis, G. and J. Fei (1964). The Development of Labor Surplus Economy. New Haven CT: Yale University Press.

Riddell, R. (2007). Does Foreign Aid Really Work? New York: Oxford University Press.

Rodrik, D. (1999). Institutions for High-Quality Growth: What are They and How to Acquire Them. Draft paper prepared for the International Monetary Fund Conference on Second-Generation Reforms, Washington DC. $<$ http://ksghome.harvard.edu/ drodrik/institutions.pdf $>$

Rodrik, D., A. Subramanian, and F. Trebbi (2002). Institutions Rule: The Primacy of Institutions Over Geography and Integration in Economic Development. NBER Working Paper No. 9305, October. National Bureau of Economic Research. <http://www.nber.org/papers/w9305>

Romer, P. (1986). Increasing Returns and Long-Run Growth. The Journal of Political Economy, 94(5):1002-1037.

Rosenstein-Rodan, P. (1943). Problems of Industrialization of Eastern and Southeastern Europe. Economic Journal, 53:202-211.

Rosenstein-Rodan, P. (1961). Notes on the Theory of the Big Push. In Economic Development for Latin America. H. Ellis (ed.). London: St. Martin's Press.

Rostow, W. (1960). The Stages of Economic Growth: A Non-Communist Manifesto. Cambridge: Cambridge University Press.

Sachs, J. (2005). The End of Poverty Economic Possibilities for Out Time. New York: Penguin Press.

Sawada, Y., H. Kohama, and H. Kono (2004). Aid, Policies, and Growth: A Further Comment. Faculty of Economics, University of Tokyo.

Solow, R. (1956). A Contribution to the Theory of Economic Growth. Quarterly Journal of Economics, 70:65-94.

Stiglitz, J. and A. Weiss (1981). Credit Rationing in Markets with Imperfect Information. American Economic Review, 71(3):393-410. 
80

Tarp, F. (2006). Aid and Development. DP 06-12, Department of Economics, University of Copenhagen.

Taylor, L. (1990). A Three-Gap Model. In Problems of Developing Countries in the 1990s. F.D. McCarthy (ed.). World Bank, Washington DC.

USAID. (1984). Nature of the Challenge to the Development of Market Economies in LDCs. In A.I.D. Policy Paper Private Enterprise Development: Chapter III. <http://www.usaid.gov/policy/ ads/200/private_enterprise/>

Van de Walle, N. (2005). Overcoming Stagnation in Aid-Dependent Countries. Washington, DC: Center for Global Development.

Wane, W. (2004). The Quality of Foreign Aid: Country Selectivity or Donor Incentives? Policy Research Working Paper 3325, Development Research Group, World Bank, Washington DC. <http:/wwwwds.worldbank.org/external/default/WDSContentServer/IW3P/IB/2004/0 7/29/000160016_20040729130731/Rendered/PDF/wps3325.pdf>

White, H. (1992). What Do We Know About Aid's Macroeconomic Impact? An Overview of the Aid Effectiveness Debate. Journal of International Development, 4(2): 121-137.

Wolfensohn, J. (1997). The Challenge of Inclusion. World Bank Annual Meetings Address, Hong Kong SAR, China. $<$ http://www.worldbank.org/html/extdr/am97/jdw_sp/jwsp97e.htm>

Wolfensohn, J. (1998). The Other Crisis. Address to Board of Governors, World Bank, Washington DC. <http://www.worldbank.org/html/ extdr/am98/jdw-sp/am98-en.htm>

Wolfensohn, J. (1999). A Proposal for a Comprehensive Development Framework (for World Bank Policy). Discussion Draft, 21 January.

Wood, B., D. Kabell, F. Sagasti and N. Muwanga (2008). Synthesis Report on the First Phase of the Evaluation of the Implementation of the Paris Declaration. Copenhagen.

World Bank (1998). Assessing Aid: What Works, What Doesn't, and Why. Oxford: Oxford University Press. $<$ http://wwwwds.worldbank. org/external/default/WDSContentServer/IW3P/IB/2000/0 2/23/000094946_99030406212262/Rendered/PDF/multi_page.pdf $>$ 
81

World Bank (2003). Toward Country-Led Development: A Multi-Partner Evaluation of the Comprehensive Development Framework. Synthesis Report. Washington DC. <http://www.um.dk/Publikationer/ Danida/English/Evaluations/EvaluationTowardCountryledDevelopment/SynthesisReport.pdf> 